\title{
Digital Media Relations Pendekatan Public Relations dalam Menyosialisasikan Social Distancing di Kota Bandung
}

\author{
Dasrun Hidayat ${ }^{1}$, Leili Kurnia Gustini ${ }^{2}$, Megawati Puspa Dias ${ }^{3}$ \\ ${ }^{1,3}$ Program Studi Ilmu Komunikasi, Fakultas Komunikasi dan Desain, Universitas Adhirajasa Reswara Sanjaya \\ J1. Sekolah International Nomor 1-2, Antapani, Bandung, Jawa Barat, 40282, Indonesia \\ ${ }^{2}$ Politeknik LP3I Bandung \\ J1. Pahlawan No.59, Sukaluyu, Kec. Cibeunying Kaler, Kota Bandung, Jawa Barat 40123, Indonesia \\ Email: dasrun@ars.ac.id ${ }^{1 *}$; leilikage@yahoo.com²; megawatipuspa3@gmail.com ${ }^{3}$; \\ *Corresponding author
}

\begin{abstract}
Bandung city government's public relations approach in conveying social distancing information is the focus of research. This phenomenon is studied because massive digital media is used, which opens up opportunities for the development of digital media relations. This research aims to analyze the public relations approach through digital media relations in disseminating social distancing policies. The research used a qualitative descriptive method with a single holistic case study approach. Primary data collection techniques through interviews with the people of Bandung City as many as eight people. Data is also taken secondary from social media@ @umasbdg. The data analysis methods used were reduction, description, and conclusion drawing. The results of the study found that the public relations of the Bandung City government contributed to the implementation of social distancing. This contribution is through a socialization program using a digital media approach. The media in question is social media with an official account @humasbdg. The account is used in several types of social media such as Instagram, Facebook, and Youtube. Social media platforms are used as a social distancing campaign strategy through a digital media relations approach. This approach can build the support of the people of Bandung City in carrying out social distancing. The contribution of this research is in the form of new policy recommendations to the Bandung City government in formulating digital media as a strategy for disseminating other policies related to the COVID-19 pandemic. Keywords: COVID-19; Digital Media Relations; Public Relations; Social Distance
\end{abstract}

\begin{abstract}
Abstrak
Pendekatan public relations pemerintah Kota Bandung dalam menyampaikan informasi social distancing merupakan fokus penelitian ini. Fenomena ini dikaji karena media digital masif digunakan sehingga membuka peluang terbangunnya digital media relations. Penelitian ini bertujuan untuk menganalisis pendekatan public relations melalui digital media relations dalam menyosialisasikan kebijakan social distancing. Penelitian menggunakan metode deskriptif kualitatifdengan pendekatan studi kasus tunggal holisitik. Teknik pengumpulan data primer melalui wawancara dengan masyarakat Kota Bandung sebanyak delapan orang. Data juga diambil secara sekunder dari media sosial @humasbdg. Metode analisis data yang digunakan yaitu reduksi, deskripsi, dan penarikan kesimpulan. Hasil penelitian menemukan bahwa public relations pemerintah Kota Bandung memberikan kontribusi terhadap pelaksanaan social distancing. Kontribusi tersebut melalui program sosialisasi dengan menggunakan pendekatan media digital. Media yang dimaksud adalah media sosial dengan akun resmi @ humasbdg. Akun tersebut digunakan dibeberapa jenis media sosial seperti Instagram, Facebook, dan Youtube. Platform media sosial digunakan sebagai strategi kampanye social distancing melalui pendekatan digital media relations. Pendekatan ini mampu membangun dukungan masyarakat Kota Bandung dalam menjalankan social distancing. Kontribusi penelitian ini berupa rekomendasi kebijakan baru kepada pemerintah Kota Bandung dalam merumuskan media digital sebagai strategi sosialisasi kebijakan lainnya terkait pandemi COVID-19.
\end{abstract}

Kata kunci: COVID-19; Digital Media Relations; Public Relations; Sosial Distancing

\section{Pendahuluan}

Coronovirus Disease (COVID-19) merupakan penyakit yang disebabkan oleh virus Severe Acute Respiratory Syndrome Cornonavirus-2 (SARS-CoV-2). Gejala yang muncul pada penderita COVID-19 diantaranya gangguan pernapasan akut, demam, batuk, dan sesak napas. Penyakit ini pertama kali muncul di Wuhan, Tiongkok pada November 2019. Penyebaran penyakit COVID-19 ditularkan dari 
manusia ke manusia secara cepat (Kaddi, Lestari, \& Adrian, 2020). Penularan COVID-19 yang mulanya di Tiongkok, kemudian menyebar ke lebih dari 190 negara lainnya (WHO, Maret 2020.

Google Analytic terkait COVID-19 mencatat sekitar lebih dari 719 ribu kasus terkonfirmasi COVID-19 sejak 15 Maret 2020 hingga 28 Desember 2020 dengan kesembuhan pasien sebesar 590 ribu jiwa. Tidak hanya masyarakat biasa saja yang terinfeksi virus corona namun tim medis juga sangat beresiko terpapar COVID-19. Tim medis yang berperan dalam penanganan COVID-19 meliputi dokter spesialis, dokter umum, apoteker, petugas laboratorium, ahli gizi, dan perawat (Husain, 2020). Pemerintah perlu melakukan upaya untuk mengurangi resiko penularan COVID-19, maka kebijakan baru berupa social distancing diterapkan.

Menyosialisasikan kebijakan pemerintah tentang social distancing sulit dilakukan secara langsung ketika pemerintah melarang adanya kerumunan dan interaksi secara langsung. Realitas ini menjadi tantangan pemerintah daerah agar mampu mengoptimalkan media berbasis digital sebagai pendekatan sosialisasi kebijakan tersebut. Social distancing merupakan usaha seseorang untuk tidak berhubungan dalam jangkauan yang rapat atau menjauhi keramaian orang (Eikenberry et al., 2020). Social distancing mulanya di keluarkan oleh lembaga kesehatan internasional World Health Organization (WHO) yang kemudian juga berkembang menjadi physical distancing (WHO, 2020). Langkah ini untuk menghentikan penularan COVID-19 di dunia. Indonesia menetapkan kebijakan social distancing setelah adanya masyarakat positif COVID-19. Social distancing merupakan salah satu upaya dalam menjalankan protokol kesehatan (Hidayat \& Noeraida, 2020). Selain social distancing, protokol kesehatan juga dapat dilakukan dengan disiplin menggunakan masker, cuci tangan, menggunakan handsanitizer, dan mengonsumsi makanan dengan nutrizi sesuai kebutuhan tubuh (Y1lmaz et al., 2020). Penelitian yang menerapkan edukasi protokol kesehatan dilakukan oleh Rahmawati et al. (2020) yang menyatakan bahwa edukasi protokol kesehatan di era new normal dilakukan dengan memanfaatkan media poster yang disosialisasikan melalui media sosial yang dapat meningkatkan meningkatkan minat baca masyarakat.

Pendekatan media digital dalam mensosialisasikan program protokol kesehatan sangat masif dilakukan. Bahkan trennya meningkat apabila dibandingkan dengan penggunaan sebelum adanya pandemi COVID-19. Sebelum pandemi hanya aktivitas tertentu saja menggunakan teknologi digital, namun saat pandemi semua aktivitas berbasis Information and Communication Technology atau ICT (Nae, 2020) meliputi bekerja, belajar, dan belanja dilakukan dari rumah secara daring. Penggunaan teknologi daring meningkat 100 persen selama pandemi (Hidayat et al., 2020). Fenomena ini menjadi menarik untuk dikaji. Jika sebelum pandemi media digital sudah diperkenalkan, tetapi kondisinya tidak masif seperti saat ini. Fokus yang diangkat adalah bagaimana memanfaatkan media digital tersebut sebagai pendekatan dalam membangun kepercayaan, dukungan, dan hubungan baik dengan masyarakat sehingga sosialisasi social distancing berjalan efektif. Adapun yang membedakan dengan penelitian sebelumnya adalah media relations yang digunakan lazimnya media konvesional, namun pada penelitian ini khusus berbicara tentang digital media relations seiring dengan kemajuan teknologi dan diperkuat oleh situasi pandemi yang mengharuskan tiap individu mengakses teknologi internet untuk mendapatkan informasi. Digital media relations dapat diartikan sebagai aktivitas berbasis media berteknologi tinggi yang digunakan oleh masyarakat modern atau disebut pula dengan istilah social media relations (Badri, 2012). Social media relations bertujuan untuk membangun hubungan baik dengan menyampaikan informasi yang dibutuhkan oleh publik melalui media sosial. Memberikan informasi yang dibutuhkan tersebut menjadi awal terbentuknya kepercayaan dan dukungan dari publik. Digital media relations atau social media relations menjadi kebutuhan seiring dengan adanya budaya baru di tengah masyarakat berupa perilaku komunikasi secara digital. 
Digital media disebut pula sebagai strategi komunikasi modern seiring dengan kemajuan teknologi. Pendekatan beralih dari konvensional ke kontemporer atau pendekatan modern. Tidak terkecuali public relations menggunakan media digital sebagai pendekatan kerja. Pendekatan ini disebut pula dengan istilah digital public relations yaitu cara kerja public relations yang terintegrasi dengan teknologi digital (Hidayat et al., 2019). Pendekatan kerja secara digital tidak dapat dihindari seiring arus informasi di media digital lebih cepat dibandingkan dengan media konvensional sehingga konsep media relations juga harus berubah ke arah digital media relaitons (Badri, 2012). Konsep media relations selalu identik dengan media konvensional yang tidak lepas dari wartawan. Media relations dapat dibangun dengan menjaga hubungan baik dengan media eksternal (Bland et al., 2005). Hadirnya digital media tentu saja merubah konsep media relations menjadi hubungan secara langsung dengan masyarakat yang secara langsung sebagai pemilik akun dari media sosialnya (Badri, 2012).

Penelitian ini fokus membahas terkait pendekatan digital media yang digunakan oleh public relations pemerintah Kota Bandung dalam mensosialisasikan social distancing. Pemerintah Kota Bandung menggunakan perencanaan kampanye public relations. Strategi kampanye public relations tersebut menggunakan pemanfaatan media digital. Media berbasis teknologi internet yang dapat menghubungkan tiap individu tanpa batas waktu dan ruang (Prasanti, 2016). Media digital yang digunakan mulai dari website lembaga hingga media sosialnya. Berbagai jenis media digital, media sosial paling banyak digunakan oleh masyarakat. Media sosial mudah dalam penggunaannya dan konten yang disuguhkan lebih bervariasi, juga terpublikasi dengan cepat dan luas (Akhmad et al., 2018). Media sosial mampu menyajikan beragam informasi dengan konsep berbeda, unik, dan menarik sehingga mendorong minat masyarakat (Artaya \& Purworusmiardi, 2019). Media sosial dinilai sebagai media bersama karena dimiliki oleh tiap individu tanpa pandang status (Hidayat, Kuswarno, et al., 2019). Ragam karakteristik dan kelebihan media sosial tersebut menjadi alasan public relations Kota Bandung memilih media sosial sebagai strategi kampanye social distancing. Kampanye yang dilakukan oleh public relations pemerintah Kota Bandung bertujuan membangun budaya baru tentang kesadaran pentingnya sosial distancing dalam upaya pencegahan COVID-19. Salah satu akun yang digunakan dalam kegiatan kampanye adalah @humasbdg.

Objek penelitian terkait sosialisasi social distancing karena sampai saat ini angka COVID-19 di Indonesia, khususnya di Kota Bandung belum dapat dikatakan membaik. Kondisi tersebut terjadi karena kurangnya kesadaran masyarakat dalam menjalankan protokol kesehatan sepeti social distancing, menggunakan masker, rutin mencuci tangan, mengurangi kontak langsung dengan orang lain, etika batuk, bersin, dan lain sebagainya. Situasi ini menjadi sorotan pemerintah Kota Bandung sehingga melalui bidang public relations pemerintah daerah mengeluarkan kebijakan sosialisasi dengan menggunakan pendekatan digital media relations. Adanya upaya menyampaikan informasi dengan baik diharapkan mampu membangun kepercayaan, kesadaran dan hubungan baik dengan masyarakat. Hubungan tersebut sebagai modal dalam menjalankan social distancing yang digalakkan oleh pemerintah.

Berdasarkan latarbelakang tersebut, penelitian ini bertujuan untuk menjelaskan pemanfaatan media digital sebagai upaya mendapatkan dukungan dari masyarakat Kota Bandung dalam melaksanakan social distancing. Aspek yang dikaji meliputi fungsi, media, dan pendekatan yang digunakan public relations pemerintah Kota Bandung. Penelitian ini juga bertujuan untuk memberikan kontribusi terhadap strategi pemerintah Kota Bandung dalam mengelola media digital sebagai pendekatan model baru dalam membangun hubungan baik dengan masyarakat. 


\section{Metode Penelitian}

Penelitian tentang pemanfaatan digital media sebagai pendekatan menyosialisasikan informasi social distancing di Kota Bandung menggunakan jenis penelitian kualitatif. Penelitian yang sifatnya alami tidak didasarkan pada setting dan masalah yang dibahas berdasarkan realitas yang terjadi di lapangan (Hidayat \& Hafiar, 2019). Kualitatif juga menempatkan peneliti sebagai bagian langsung dari masalah yang diteliti (Yin, 2014). Peneliti dapat melakukan interaksi langsung dengan kelompok masyarakat sebagai subjek penelitian yakni masyarakat Kota Bandung. Keterlibatan peneliti berupa kegiatan observasi dan wawancara yang bertujuan untuk mengumpulkan data primer yang dibutuhkan dalam proses penelitian. Keterlibatan peneliti secara langsung sehingga penelitian kualitatif tidak bebas nilai. Adanya interpretasi yang didasari oleh pengetahuan dan pengalaman peneliti sehingga hasil penelitian tidak dapat digeneralisasi. Penelitian ini juga memilih studi kasus tunggal holistik. Studi yang memposisikan satu kasus sebagai fokus penelitian (Denzin \& Lincoln, 2009). Kasus dalam penelitian ini adalah pendekatan sosialisasi social distancing dengan meggunakan digital media relations di tengah pandemi COVID-19. Kasus terebut sekaligus sebagai objek penelitian. Salah satu alasan peneliti menggunakan studi kasus tunggal karena kasus tersebut dapat dijelaskan secara baik berdasarkan teori sehingga kasus yang dipilih dapat dibuktikan kebenarannya.

Teknik pemilihan informan atau subjek penelitian dilakukan secara purposif. Teknik purposif mensyaratkan kriteria yang tepat ditentukan berdasarkan kebutuhan penelitian (Pratama \& Hidayat, 2020). Kriteria subjek penelitian ini adalah pengelola media sosial pemerintah Kota Bandung. Masyarakat yang pernah mengakses media kampanye social distancing pemerintah Kota Bandung. Subjek juga tinggal di Kota Bandung dan bersedia untuk dijadikan sebagai sumber data. Subjek sebanyak 8 delapan orang terdiri dari staf public relations, pelajar, mahasiswa, dan karyawan di lembaga serta perusahaan di Kota Bandung.
Data diperoleh dari subjek atau informan melalui teknik wawancara dan kajian literatur. Wawancara untuk mendapatkan data primer yang dilakukan secara daring mengingat hingga saat ini kasus COVID-19 di Kota Bandung belum membaik. Data sekunder peneliti peroleh dari berbagai informasi yang diposting di website dan akun media sosial@humasbdg. Data yang terkumpul kemudian diolah melalui proses analisis data meliputi reduksi, deskripsi, dan penarikan kesimpulan data. Istilah lain dari analisis data yakni proses identifikasi data dengan melakukan konstruk data pertama, konstruk data kedua, dan konstuk data ketiga (Hidayat, Hafiar, et al., 2019). Tahapan reduksi atau konstruk data pertama yakni peneliti membuat naskah hasil wawancara berdasarkan urutannya. Tahapan deskripsi atau konstruk data kedua, peneliti mengklasifikasikan data berdasarkan subtema pada pertanyaan penelitian meliputi jenis media, pemetaan konten, dan respons masyarakat terhadap media digital yang digunakan oleh pemerintah Kota Bandung. Tahapan deskripsi disebut pula sebagai langkah menyusun (display) data sebelum ditarik kesimpulan atau membuat analisis data tersebut sesuai dengan tiap pertanyaan penelitian. Tahapan analisis data disebut pula dengan tahapan konstruk data ketiga. Tahapan ini peneliti melakukan analisis berdasarkan teori-teori relevan sehingga data berkaitan kasus pendekatan sosialisasi social distancing yang dilakukan oleh public relations pemerintah Kota Bandung dapat dipertanggungjawabkan kebenarannya.

\section{Hasil Penelitian dan Pembahasan}

Berdasarkan hasil penelitian bahwa public relations Kota Bandung berkontribusi dalam mensosialisasikan kebijakan social distancing. Hal itu sebagai salah satu langkah dalam penanggulangan COVID-19. Public relations berusaha untuk mencari informasi yang dibutuhan oleh masyarakat Kota Bandung. Adapun cara yang dilakukan adalah membuat survei terkait pengetahuan masyarakat tentang COVID-19, khususnya social distancing. Survei dilakukan untuk mengetahui kebutuhan 
masyarakat atas informasi COVID-19. Demikian yang dituturkan informan bahwa langkah pemerintah Kota Bandung sudah bagus dengan melibatkan masyarakat. Informan lainnya juga mengakui informasi terkait social distancing sudah lengkap dan sesuai kebutuhan. Senada dengan yang dituturkan informan berikutnya bahwa informasi tentang COVID-19 sudah sesuai dan bisa diakses dari media sosial pemerintah Kota Bandung. Pengakuan para informan selaras dengan fungsi public relations sebagai fasilitator komunikasi. Fungsi public relations selain membentuk image yang positif terhadap pemerintah juga menjalankan fungsinya membangun hubungan baik antara pemerintah dengan masyarakat. Terwujudnya hubungan baik merupakan bentuk keberhasilan public relations pemerintah Kota Bandung dalam mengaplikasikan peran serta mengoptimalkan fungsinya. Salah satu perannya adalah menjadi fasilitator yang berusaha untuk menjadi perantara untuk mengetahui dan menyatukan antara keinginan lembaga dengan public (Yayu et al., 2019). Tren perilaku masyarakat menjadi modal public relations dalam memahami kebutuhan publik (Baines et al., 2004). Public relations juga diharapkan mampu memfasilitasi komunikasi dua arah atau timbal-balik (Parthawa, Krisyantoro, R., 2015). Komunikasi dua arah merupakan komunikasi terencana dalam upaya membangun hubungan baik (Herlina, 2015).

Pada pelaksanaan sosialisasi social distancing, public relations Kota Bandung juga mengikuti perkembangan perilaku masyarakat terkait pelaksanaan social distancing. Upaya ini dilakukan dengan menggunakan beberapa media CCTV yang dipasang di beberapa titik kerumunan masyarakat. Hal ini senada diungkapkan oleh staf public relations Kota Bandung bahwa semua membatasi interaksi secara langsung sehingga pemerintah juga memantau perilaku masyarakat melalui CCTV. Data yang diperolah dari CCTV dijadikan bahan evaluasi terkait analisis perilaku masyarakat dalam menerapkan social distancing. Menurut pengakuan informan sampai saati ini social distancing dipatuhi dan berkontribusi terhadap pencegahan penyebaran virus COVID-19. Temuan berikut ini memperkuat temuan sebelumnya terkait fungsi public relations pemerintah Kota Bandung. Temuan ini pula selaras dengan hasil penelitian sebelumnya bahwa public relations harus mampu melakukan interpretasi, analisis terhadap perilaku masyarakat (Apriananta \& Wijaya, 2018). Kekuatan public relations dalam membuat analisis publik berguna untuk memetakan strategi program sehingga sesuai dengan kebutuhan publik dan lembaga. Analisis juga digunakan sebagai data perencanaan program yang dibuat secara utuh (Juanda, 2017).

Hasil penelitian juga menemukan jenis media yang digunakan public relations Kota Bandung dalam mensosialisasikan social distancing. Public relations dalam menginformasikan kebijakan social distancing melalui media sosial. Media sosial meliputi Instagram, Facebook, dan Youtube. Dari tiga jenis media sosial tersebut Instagram yang lebih banyak diakses oleh masyarakat. Realitas ini diakui oleh informan sebagai bentuk kebiasaan atau perilaku komunikasi yang dibangun oleh tren penggunaan media sosial Instagram. Pengakuan ini juga diperkuat oleh penelitian sebelumnya yang menyebutkan bahwa media sosial Instagram lebih banyak digunakan oleh masyarakat. Pilihan Instagram dilatar belakangi oleh kemudahan dan kecepatan akses informasi. (Elvina, 2019). Instagram berasal dari kata instan artinya cepat tanpa membutuhkan proses yang lama (Subekti et al., 2020). Instagram lebih banyak digunakan oleh kalangan remaja atau milenial Kota Bandung. Remaja memilih Instagram karena trend yang mendorong perilaku komunikasi menggunakan media sosial Instagram. Perilaku komunikasi ditengah kemajuan teknologi digital akan terjadi dinamis sehingga memungkinkan bermunculan platform baru (Hidayat et al., 2018). Kecenderungan menggunakan Instagram pada masa pandemi karena dilatar belakangi oleh perilaku komunikasi masyarakat yang cenderung memilih media tersebut.

Pemilihan media digital sebagai saluran informasi tentang social distancing dan COVID-19 juga diakses melalui Facebook. Media sosial 
Tabel 1. Pemetaan Penggunaan Media Sosial Sosialisasi Social Ditancing

\begin{tabular}{lll}
\hline Jenis Media Sosial & Kelompok Usia & Kelompok Pekerjaan \\
\hline Instagram & Remaja, Milenial & Pelajar, Mahasiswa, \\
& & Pegawai Muda \\
Facebook & Dewasa & $\begin{array}{l}\text { Pegawai, Karyawan, Ibu } \\
\text { Rumah Tangga }\end{array}$ \\
Youtube & Semua Usia & Semua Lapisan \\
\hline
\end{tabular}

Sumber: Hasil Penelitian (2020)

Facebook digunakan oleh kelompok masyarakat yang usianya relatif dewasa. Diantara informan penelitian yang mengaku memilih Facebook berprofesi sebagai karyawan dengan usia di atas 40 tahun yang menyatakan bahwa lebih memilih Facebook untuk mengetahui informasi mengenai COVID-19. Informan memilih Facebook digunakan sudah sejak dahulu karena merasa malas untuk beralih ke media sosial yang lainnya.

Facebook sebagai salah satu media sosial yang muncul sebelum Instagram hingga saat ini tetap digunakan oleh masyarakat. Facebook ratarata digunakan oleh generasi sebelum munculnya media sosial lainnya seperti Twitter dan Instagram (Budiman et al., 2019). Facebook digunakan selain karena faktor kedekatan secara usia dan generasi, juga dianggap sebagai media yang paling mudah diakses informasinya. Tidak jauh berbeda dengan media sosial Instagram, Facebook juga dianggap oleh penggunanya sebagai media sosial yang paling sesuai dengan kebutuhan. Perbedaan dalam memilih platform media sosial dalam mengakses informasi COVID-19 tentu saja didasari oleh pengetahun dan pengalaman tiap individu. Perbedaan tersebut tetap mengacu pada kemudahan dalam mengakses informasi.

Youtube juga digunakan oleh masyarakat Kota Bandung dalam mencari informasi terkait COVID-19 khususnya social distancing. Youtube dianggap lebih lengkap dalam menyajikan pesan COVID-19. Youtube juga dianggap lebih persuasif dalam mengemas pesan sehingga masyarakat memilih media tersebut. Informan menyatakan selain menggunakan Instagram, juga mendapat informasi dari Youtube. Youtube memberikan informasi yang lebih lengkap dan mudah dipahami karena dikemas menggunakan pesan animasi yang menceritakan tentang social distancing.

Youtube dipilih karena tidak membutuhkan konsentrasi penuh. Salah seorang informan menyatakan Youtube bisa dinikmati sembari melakukan aktivitas lainnya. Tanggapan informan terkait alasan menggunakan Youtube dalam mengakses informasi social distancing karena media sosial Youtube merupakan media yang memadukan antara pesan visual dan audio atau audiovisual (Budiman et al., 2019). Variasi pesan yang ditampilkan pada saluran Youtube membuat media sosial yang satu ini dipilih oleh semua lapisan masyarakat. Youtube digunakan oleh semua lapisan masyarakat mulai dari anak-anak, remaja, dan usai dewasa.

Jenis media sosial yang lebih banyak digunakan oleh masyarakat dalam mengakses informasi social distancing adalah Instagram, Facebook, dan Youtube (Tabel 1). Penggunaan media sosial tersebut merupakan wujud dari penggambaran perkembangan teknologi yang potensial terjadinya kegiatan pertukaran berbagai konten informasi, baik dapat berupa pegetahuan, pengalaman, dan pandangan-pandangan baik yang bersifat audio, visual, bahkan audiovisual (Pienrasmi, 2015). Sebelumnya Line sebagai media sosial juga digunakan oleh masyarakat sebagai media sosialisasi (Putri, 2018). Media sosial digunakan oleh semua lembaga pemerintah maupun swasta sebagai alat komunikasi (Marpianta \& Hendriyani, 2019). Efektivitas media sosialbukan sekadar berupayamemberikan pesan kepada jutaan khalayak sekaligus, akan tetapi lebih karena media sosial juga menerapkan fungsi mendidik, mempengaruhi, mentransformasikan, dan menghibur (Anisti \& 
Hidayat, 2015). Ragam media sosial digunakan sebagai pendekatan sosialisasi social distancing agar dapat mencakup semua kalangan pengguna media sosial. Selain itu, untuk mengoptimalkan fitur-fitur yang berbeda dari tiap jenis media sosial tersebut. Hal yang dikhawatirkan tidak semua masyarakat hanya menggunakan satu jenis media sosial saja jadi pemerintah kota memiliki tiga media sosial, masing-masing memiliki fitur yang dapat digunakan untuk evaluasi. Jenisjenis media sosial tersebut memiliki fitur yang berbeda dalam penyajian pesan-pesan social distancing. Misalnya, Instagram menunjukkan data statistik followers dan interactions dari para followers terhadap suatu konten yang dapat berupa tulisan, foto dan video. Dari fitur tersebut dapat diketahui ketertarikan masyarakat terhadap konten social distancing yang dipublikasikan. Selain itu, data statistik dapat dijadikan bahan evaluasi program sosialisasi social distancing.

Youtube merupakan salah satu media sosial berbasis video yang berdurasi pendek maupun panjang. Media ini dakui sangat membantu untuk menarik perhatian masyarakat Kota Bandung yang malas untuk membaca konten berupa tulisan, masyarakat yang tidak ada waktu untuk membaca, dan masyakarat yang lebih tertarik dengan media audiovisual. Public Relations pemerintah Kota Bandung sangat menyadari bahwa pemanfaatan beberapa jenis media sosial karena setiap jenisnya memiliki karakteristik berbeda dan sekaligus kelebihan media tersebut.

Sosialisasi kebijakan social distancing melalui media sosial merupakan alat komunikasi yang tercanggih seiring kemajuan teknologi informasi. Hadirnya media sosial menjadikan strategi komunikasi lebih aktif dan terbuka (Mustika, 2018). Media sosial menyuguhkan pilihan baru untuk setiap aspek proses komunikasi dalam kegiatan public relations, mulai dari tahap riset sampai ke tahap evaluasi. Media sosial dapat digunakan untuk mendistribusikan konten dengan makna pesan tertentu kepada komunikan yang lebih luas dan cepat. Kekuatan yang dimiliki oleh media sosial menjadi alasan public relations pemerintah Kota Bandung memilih digital media relations sebagai pendekatan kerja. Pemilihan digital media relations juga dilatar belakangi oleh situasi pandemi yang mengharuskan aktivitas dari rumah melalui teknologi berbasis internet. "Semenjak COVID-19 ini muncul dengan terpaksa melakukan aktivitas dirumah saja, bukan hal yang mudah untuk dilakukan bagi sebagian orang karena pasti akan merasakan jenuh dan ruang gerak yang terbatas. Akan tetapi sangat bersyukur dengan kemajuan teknologi informasi saat ini, dengan adanya media sosial dapat membantu untuk meminimalisir rasa jenuh tersebut. Selain itu, dapat menunjang aktivitas kegiatan seharihari, juga mendapatkan informasi-informasi yang membantu dalam menghadapi pandemi COVID-19 ini" (Widya, 10 Juni 2020).

Media sosial adalah salah satu sumber informasi yang dipakai oleh masyarakat pada saat ini. Pilihan ini dikarenakan media sosial dapat menyebarkan informasi dengan cepat dan luas. Penggunaan media sosial sebagai pendekatan sosialisasi karena dinilai hemat biaya karena tidak memerlukan banyak orang untuk mengelolanya. Bahkan hingga Januari 2020, Indonesia termasuk negara urutan ke-empat pengguna media sosial setelah sebelumnya India, Amerika Serikat, Brazil, dan Indonesia (Ramadhan, 2020). Data tersebut menjadi alasan kuat penggunaan digital media relations sebagai pendekatan kerja mensosialisasikan social distancing. Public Relations pemerintah Kota Bandung dinilai tepat dalam memanfaatkan peluang yang ada di media internet untuk mendukung pelaksanaan kegiatan public relations. Mengingat penggunaan media sosial sangat tinggi sehingga diharapkan dapat memaksimalkan penyebaran informasi social distancing yang mudah diakses untuk semua kalangan, dan mendongkraktujuan sesuai sasaran.

Sosialisasi yang dilakukan public relations pemerintah Kota Bandung bersifat konsisten dan berkelanjutan dengan konten-konten yang terorganisir dengan baik sehingga setiap harinya konten tersebut terus mengisi akun media sosial dan tidak terjadi kekosongan. Konten juga selalu di-update agar masyarakat selalu mendapatkan perkembangan tebaru terkait COVID-19. Penyajian pesan secara kreatif sehingga mampu menarik perhatian masyarakat. Sosialisasi social distancing melalui media sosial merupakan 


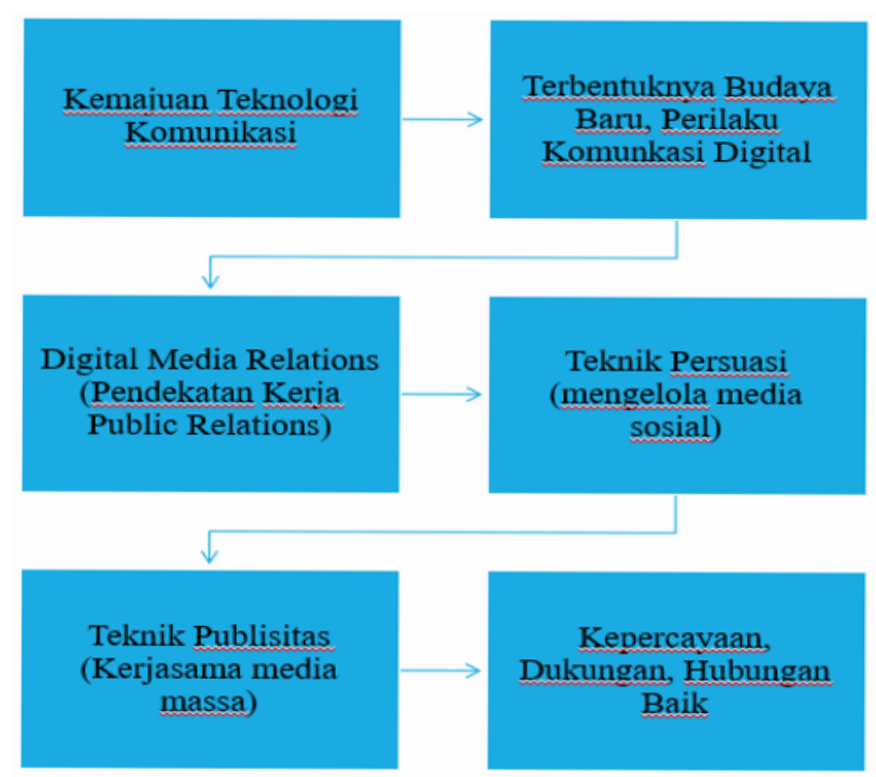

Gambar 1. Proses Digital Media Relations Pendekatan Kerja Public Relations

Sumber: Hasil Penelitian (2020)

salah satu komunikasi yang revolusioner yang mempermudah pelaksanaan kegiatan public relations pemerintah Kota Bandung. "Dari media sosial saya banyak mengonsumsi informasi terkini terutama perihal pandemi COVID-19 ini. Mulai dari perkembangan dan langkah pencegahannya. Hal yang menarik perhatian saya untuk melihat dan membaca konten-konten yang diunggah oleh akun resmi media sosial Humas Pemerintah Kota Bandung adalah dalam setiap harinya selalu ada konten yang diunggah oleh Humas Pemerintah Kota Bandung sehingga dari konsistensi tersebut konten yang diunggah selalu muncul di laman beranda setiap saya membuka media sosial." (Pebiyan, 10 Juni 2020). Daya tarik masyarakat untuk mengakses media sosial pemerintah Kota Bandung karena media tersebut dinilai memiliki kemasan informasi yang menarik dan mudah dipahami. Strategi penyebaran informasi yang konsisten juga sangat mempengaruhi perhatian masyarakat. Hasil penelitian juga menemukan teknik sosialisasi juga menjadi alasan kepercayaan masyarakat terhadap media sosial yang dikelola oleh pemerintah Kota Bandung. Ada dua teknik sosialisasi yang digunakan oleh public relations pemerintah Kota Bandung dalam mensosialisasikan social distancing yaitu techniqueofpublicity dantechnique ofpersuasion.
Technique of publicity digunakan oleh public relations dengan memanfaatkan ragam media massa selain media sosial seperti media radio untuk mengirim release dan talkshow. Kerjasama dengan radio diharapkan dapat mengoptimalkan penyebaran informasi urgensi melaksanakan social distancing dalam meminimalisasi penyebaran COVID-19. Pertimbangan memanfaatkan radio karena hingga saat ini masih banyak masyarakat Kota Bandung aktif mendengarkan radio. Upaya optimalisasi sosialisasi diharapkan masyarakat lebih menyadari adanya wabah sehingga mengikuti protokol kesehatan sangat diutamakan.

Technique of persuasion merupakan strategi yang diterapkan pada penggunaan media sosial. Tujuan dari strategi adalah membujuk atau menggalang dukungan masyarakat melalui teknik sugesti persuasi. Dalam hal ini public relations pemerintah Kota Bandung terus mengajak masyarakat untuk ikut berperan aktif dalam meminimalisasi penyebaran COVID-19 dengan melakukan social distancing. Langkah yang dilakukan dengan menyampaikan informasi ter-update tentang penyebaran kasuskasus COVID-19 di wilayah Kota Bandung. Berikut pengakuan staf humas Kota Bandung. 
"Mengoptimalkan berbagai media yang dimiliki seperti website, instagram, dan facebook, terus mengajak masyarakat untuk tetap patuh dalam menjalankan social distancing. Ini kan buat kebaikan warga, jadi ya kita harus terus sosialisai sampai situasi normal lagi." (Staf Humas Kota Bandung, 10 Juni 2020) Pelaksanaan sosialisasi mengenai social distancing berfokus pada pentingnya protokol kesehatan. Staf Humas Kota Bandung menyatakan "Fokus kita melakukan publikasi mengenai penyebaran covid-19 di Bandung agar masyarakat aware dalam menjalankan protokol kesehatan seperti social distancing, tujuanya jelas supaya wabah ini tidak meluas". Strategi yang digunakan (Gambar 1) sebagai pendekatan kerja public relations menggunakan digital media relations dengan mengkolaborasikan antara media sosial dengan media radio kontemporer yang dapat diakses melalui radio streaming. Strategi tersebut membuktikan bahwa pendekatan kerja public relations harus update dengan menyesuaikan perkembangan teknologi. Pendekatan kerja melalui digital media relations merupakan perubahan cara kerja dengan mengintegrasikan teknologi di dalamnya. Langkah ini tentu saja membantu dan mempermudah pencapaian tujuan public relations pemerintah Kota Bandung dalam mensosialisasikan kebijakan social distancing.

Digital Media Relations yang digunakan oleh public relations dalam menyosialisasikan social distancing dinilai bermanfaat baik untuk masyarakat maupun pemerintah Kota Bandung karena informasi dari pemerintah lebih dipercaya. Hal senada juga diungkapkan informan berikutnya bahwa agar terhindar dari hoaks tentang COVID-19 leboh baik akses informasi resmi dari pemerintah kota. Informan lainnya juga menuturkan informasi dari media pemerintah pasti leboh akurat sehingga lebih percaya dengan saluran media pemerintah. Pernyataan tentang kepercayaan informan terhadap informasi yang disampaikan oleh media sosial pemerintah
Kota Bandung tersebut mencerminkan adanya dukungan dari masyarakat. Dukungan dibangun karena adanya hubungan baik antar pihak (Austin \& Pinkleton, 2006). Digital media seperti media sosial yang sedang booming dapat dijadikan sebagai alat membangun hubungan dengan publik. Arus informasi melalui media sosial relatif lebih tinggi dan cepat sehingga karakteristik tersebut dapat dimanfaatkan oleh tiap public relations sebagai pendekatan kerja (Badri, 2012). Digital media relations mampu membantu mempertahankan identitas pemerintah sebagai pelayan masyarakat. Digital media relations juga dapat memfasilitasi terbangunnya hubungan dengan publik yang lebih baik dengan cara-cara yang baik dan benar, cepat, dan luas.

Upaya public relations pemerintah Kota Bandung dalam menyampaikan pesan tentang COVID-19 dan social distancing melalui beberapa jenis media sosial sangat berdampak positif bagi masyarakat maupun pemerintah Kota Bandung. Manfaat yang dirasakan berupa kenyamanan beraktivitas tanpa adanya kekhwatiran. Hingga saat ini masyarakat sudah kembali beraktivitas dengan memperhatikan protokolkesehatanmeliputi jagajaraksosial,jarak fisik, menggunakan masker, disiplin mencuci tangan atau menggunakan handsanitaizer, dan membiasakan mengkonsumsi makanan sesuai nutrisi yang dibutuhkan oleh tubuh.

Sosialisasi social distancing yang dilakukan oleh public relations pemerintah Kota Bandung dapat dikatakan berhasil dalam merubah perilaku masyarakat. Gerakan sosialisasi diharapkan dapat menumbuhkan kesadaran masyarakat pentingnya menjalankan protokol kesehatan. Tindakan ini tetap menjadi fokus pemerintah karena hingga saat ini trend kasus penyebaran COVID-19 belum menurun. Adanya kesadaran penerapan social distancing dinilai dapat membantu dalam menekan angka penyebaran COVID-19 di Indonesia khususnya di Kota Bandung. 


\section{Simpulan}

Public Relations pemerintah Kota Bandung menggunakan digital media relations sebagai pendekatan sosialisasi kebijakan social distancing. Penggunaan pendekatan ini karena media digital dinilai sedang menjadi trend dan digunakan oleh masyarakat. Adapun digital media yang dipilih adalah media sosial meliputi Instagram, Facebook, dan Youtube. Ragam media sosial digunakan sebagai digital media relations karena tiap media sosial memiliki karakteristik berbeda dan sekaligus menjadi kelebihan dari tiap media tesebut. Kunci dari keberhasilan dalam memanfaatkan media sosial tersebut karena public relations mampu mengelola media sosial secara berkesinambungan. Aspek yang menjadi fokus perhatian adalah waktu update informasi, jenis informasi, dan konsep konten yang disajikan menyesuaikan karakteristik dari tiap media sosial.

Pelaksanaan pendekatan kerja public relations menggunakan dua teknik yaitu persuasi dan teknik publikasi. Teknik persuasi dengan mengoptimalkan konten kreatif di media sosial, sedangkan teknik publikasi dengan memanfaatkan kerjasama media massa seperti radio jejaring internet atau radio streaming. Teknik persuasi maupun teknik publikasi dinilai mampu mempermudah pencapaian tujuan yaitu membangun kesadaran masyarakat untuk menjalakan protokol kesehatan salah satunya menjaga jarak sosial (social distancing).

Digital media relations sebagai pendekatan kerja public relations efektif menyosialisasikan social distancing karena adanya dukungan masyarakat Kota Bandung dalam menjalankan social distancing. Dukungan terbentuk atas kepercayaan masyarakat terhadap informasi yang disampaikan di media digital meliputi media sosial dan radio streaming. Kondisi tersebut juga membuktikan bahwa di masa pandemi maupun pasca pandemi digital media relations menjadi solusi dalam membangun hubungan baik dengan masyarakat yang saat ini perilaku komunikasi kecenderungannya menggunakan teknologi berbasis internet. Hasil penelitian ini diharapkan mampu memberikan kontribusi terhadap cara kerja public relations di tengah teknologi modern. Hasil penelitian juga dapat memberikan kontribusi terhadap arah kebijakan yang akan diambil oleh pemerintah Kota Bandung dalam menghadapi situasi pandemi atau pasca pandemi.

\section{Daftar Pustaka}

Akhmad, R. A., Unde, A. A., \& Cangara, H. (2018). Fenomenologi Penggunaan Televisi Dan Media Sosial Dalam Menyikapi Budaya Pop Korea Di Kalangan Remaja Makassar. Jurnal Komunikasi KAREBA, 7(1), 16-22. https://doi.org/: http:// dx.doi.org/10.31947/kareba.v7i1.5246 Anisti, \& Hidayat, D. (2015). Pemanfaatan Media Cyber Pr Jelang Asean Community. Jurnal Ilmu Komunikasi (J-IKA), II(1), 11-22. Apriananta, Y. J., \& Wijaya, L. S. (2018). Penggunaan Website Dan Media Sosial Dalam Membangun Citra Positif Perguruan Tinggi. Komunikatif, 7(2), 187-209. Artaya, I. P., \& Purworusmiardi, T. (2019). Efektifitas Marketplace Dalam Meningkatkan Konsentrasi Pemasaran Dan Penjualan Produk Bagi Umkm Di Jawa Timur. Ekonomi Dan Bisnis, Universitas Narotama Surabaya. https:// doi.org/10.13140/RG.2.2.10157.95206 Austin, E. W., \& Pinkleton, B. E. (2006). Strategic Public Relations Management. Laurence Erlbaum Asociates Publishers. www.erlbaum.com Badri, M. (2012). Social Media Relations: Strategi Public Relations di Era Web 2 . 0. Jurnal Risalah, 21(April 2012). Baines, P., Egan, J., \& Jefkins, F. (2004). Public Relations Contemporary Issues and Techniques (1st ed.). Jordan Hill. Bland, M., Theaker, A., \& Wragg, D. (2005). Effective Media Relations: How to get results. https://doi.org/ebrary Budiman, Arif, E., \& Roem, E. R. (2019). Pemanfaatan Media Sosial Sebagai Sarana PromosiPerpusdaKabupatenBelitungTimur. Jurnal Ranah Komunikasi (JRK), 3(1), 34-44. https://doi.org/10.25077/rk.3.1.34-44.2019 
Denzin, N. K., \& Lincoln, Y. S. (2009). Handbook of Qualitative Research (2nd ed.). Pustaka Pelajar. Eikenberry, S. E., Mancuso, M., Iboi, E., Phan, T., Eikenberry, K., Kuang, Y., Kostelich, E., \& Gumel, A. B. (2020). To mask or not to mask: Modeling the potential for face mask use by the general public to curtail the COVID-19 pandemic. Infectious Disease Modelling, 5, 293-308. https:// doi.org/10.1016/j.idm.2020.04.001 Elvina, E. (2019). Pengaruh Penggunaan Media Sosial Terhadap Pengembangan Usaha Kecil Menengah (UKM). Ecobisma (Jurnal Ekonomi, Bisnis Dan Manajemen), 2(1), 106118. https://doi.org/10.36987/ecobi.v2i1.722 Herlina, S. (2015). Strategi Komunikasi Humas Dalam Membentuk Citra Pemerintahan di Kota Malang. Jurnal Ilmu Sosial dan Politik, 4(3). Hidayat, D., Anisti, Purwadhi, \& Wibawa, D. (2020). Crisis Management and Communication Experience in Education During the CoVid-19 Pandemic in Indonesia. Jurnal Komunikasi: Malaysian Journal of Communication, 36(3), 67-82. https:// doi.org/10.17576/JKMJC-2020-3603-05

Hidayat, D., \& Hafiar, H. (2019). Nilainilai budaya soméah pada perilaku komunikasi masyarakat Suku Sunda. Jurnal Kajian Komunikasi, 7(1), 84-96.

Hidayat, D., Hafiar, H., \& Anisti. (2019). Tofu Product Branding for Culinary Tourism of Sumedang, Indonesia. Komunikator, 11(2).

Hidayat, D., Kuswarno, E., Ramdhan, M., \& Ridho ILahi, M. (2019). Digital Media dan Bisnis. Ars Pers. Hidayat, D., Kuswarno, E., Zubair, F., \& Hafiar, H. (2018). Public Relations Communication Behavior Through a Local-Wisdom Approach: The Findings of Public Relations Components Via Ethnography as Methodology. Malaysian Journal of Communication, 34(3), 56-72. Hidayat, D., \& Noeraida. (2020). Pengalaman Komunikasi Siswa Melakukan Kelas Online Selama Pandemi COVID-19. Jurnal
Ilmu Komunikasi Efek, 3(2), 172-182. https://doi.org/10.32534/jike.v3i2.1017 Hidayat, D., Ramdhan, M., \& Absor Abdallah, A. (2019). Digital Public Relations. Ars Pers. Husain, A. (2020). Komunikasi Kesehatan Dokter dan Pasien Berbasis Kearifan Lokal Sipakatau di Masa Pandemi. Jurnal Ilmu Komunikasi, 18(2), 126-141. https://doi.org/10.31315/jik.v18i2.3546 Juanda, H. (2017). Media Sosial sebagai Penyebarluasan Informasi Pemerintah Aceh. Jurnal Peurawi, 1(1), 1-22. Kaddi, S., Lestari, P., \& Adrian, D. (2020). Komunikasi Keluarga Dalam Pencegahan Coronavirus Disease 2019. Jurnal Ilmu Komunikasi, 18(1), 63-74. https:// doi.org/10.31315/jik.v18i1.3701

Marpianta, D. A., \& Hendriyani. (2019). Influence of Use of Social Media of Government Agencies on Trust to the Government : Study on Social Media Owned by Dinas Penanaman Modal dan Pelayanan Terpadu Satu Pintu Provinsi DKI Jakarta. Jurnal Komunikasi Indonesia, VIII(2). Mustika,R.(2018).EtikaBerkomunikasiDiMedia Online Dalam Menangkal Hoax. Diakom: Jurnal Media Dan Komunikasi, 1(2), 4350. https://doi.org/10.17933/diakom.v1i2.30 Nae, N. (2020). Online Learning During The Pandemic: Where Does Japan Stand?. Euromentor Journal, XI(June). Parthawa, Krisyantoro, R., dan W. (2015). A Test Of Five Factor Model on Different Roles of Government and Private Public Relations Practitioners in Indonesia. Global Journal of Human Social Science, XV, 17-22.

Pienrasmi, H. (2015). Pemanfaatan Social Media Oleh Praktisi Public Relation Di Yogyakarta. Jurnal Komunikasi, 9(2), 199-210. Prasanti,D.(2016). Perubahan MediaKomunikasi Dalam Pola Komunikasi Keluarga Di Era Digital. Jurnal Commed, 1(1), 2527-8673. Pratama, N. A., \& Hidayat, D. (2020). Pengetahuan dan Perilaku Masyarakat Memaknai Social Distancing. Jurnal Digital Media \& Relationship, 2(1), 1-10. 
Putri, N. R. (2018). The Impact of Social Media Campaign Time Scheduling on FirstTime Voters' Political Knowledge: An Experiment on Social Media LINE Campaign Among First-Time Voters in East Jakarta. Jurnal Komunikasi Indonesia, VII(3).

Rahmawati, R., Rahmah, S. F., Mahda, D. R., Purwati, T., Utomo, B. S., \& Nasution, A. M. (2020, December). Edukasi Protokol Kesehatan dalam Menjalankan New Normal di Masa Pandemik Melalui Media Poster. In Prosiding Seminar Nasional Pengabdian Masyarakat LPPM UMJ, 1(1).

Ramadhan, B. (2020). Data Internet di Indonesia dan Perilakunya Tahun 2020. Subekti, P., Hafiar, H., \& Bakti, I. (2020). Penggunaan Instagram oleh Badan Penanggulangan Bencana Daerah untuk mengoptimalkan destination branding Pangandaran. PRofesi Humas, 4(2), 174-192. WHO. (2020). \#Covid19 Coronavirus Disease 2019: Situational Report 72. DroneEmprit, 2019(April), 1-19. Retrieved from. Yayu, N., Hidayat, D., \& Suhadi, M. (2019). Pendekatan Intercultural Communication Pada Public Relations PT Santos Dalam Membangun Komunikasi Empati. PRofesi, 4(1), 1-22. Yin, R. K. (2014). Study Kasus: Desain dan Metode (1st ed.). Rajawali Pers. Y1lmaz, H. Ö., Aslan, R., \& Unal, C. (2020). Effect of the COVID-19 Pandemic on Eating Habits and Food Purchasing Behaviors of University Students, 15(3), 154-159. https://doi.org/10.21109/kesmas.v15i3.3897 